\title{
Use of larval migration inhibition assay for the evaluation of anthelmintic resistance in dairy heifers in Puerto Rico'
}

\author{
Lorraine López-Soberal ${ }^{2}$, Guillermo Ortiz-Colón ${ }^{3}$, \\ Melvin Pagán-Morales ${ }^{4}$ and Esbal Jiménez-Cabán ${ }^{5}$
}

J. Agric. Univ. P.R. 99(2):11 7-124 (2015)

\begin{abstract}
Ivermectin (IVM) resistance of Cooperia spp. in dairy heifers from Puerto Rico was evaluated using the larval migration inhibition assay (LMIA). In eight of the farms where anthelmintic resistance had previously been evaluated using a fecal egg count reduction test (FECRT), third stage larvae $\left(\mathrm{L}_{3}\right)$ were recovered from fecal cultures prior to the administration of IVM treatment. The effective concentration at which $50 \%$ of larval migration is inhibited $\left(\mathrm{EC}_{50}\right)$ was determined in susceptible and resistant Cooperia spp. isolates from one farm. The susceptible and resistant isolates had an $\mathrm{EC}_{50}$ of $0.7224 \mu \mathrm{M}$ and an $\mathrm{EC}_{50}$ of $7.0778 \mu \mathrm{M}$, respectively. This indicates that on average, larvae from the resistant isolate are $10 \mathrm{X}$ more resistant than those from the susceptible isolates. However, the LMIA was unable to discriminate consistently between susceptible and resistant larvae obtained from dairy farms evaluated. In one case, an $\mathrm{EC}_{50}$ value of $0.7263 \mu \mathrm{M}$, which is close to that of the susceptible isolate, did not agree with the FECR result of $-136.19 \%$ documented on this farm. In two additional instances the assay was unable to discriminate between susceptible and resistant isolates. Indeed LMIA $\mathrm{EC}_{50}$ values obtained from some resistant isolates were lower than the $\mathrm{EC}_{50}$ value from susceptible isolates, whereas their FECRT results indicated that resistance to IVM was present. Possibly, the FECRT could have given a false positive for macrocyclic lactones resistance at these two farms. Therefore, more studies are needed to validate the effectiveness of the LMIA to detect anthelmintic resistance to macrocyclic lactones in Cooperia spp. larvae isolated from bovine fecal field samples.
\end{abstract}

Key words: Ivermectin, Cooperia, macrocyclic lactones, fecal egg count reduction test

${ }^{1}$ Manuscript submitted to Editorial Board 26 February 2015.

${ }^{2}$ Former Graduate Student, Department of Animal Sciences, College of Agricultural Sciences. Mayagüez Campus, University of Puerto Rico.

${ }^{3}$ Associate Professor, Department of Animal Sciences, College of Agricultural Sciences. Mayagüez Campus, University of Puerto Rico.

${ }^{4}$ Professor, Department of Ánimal Sciences, Agricultural Experiment Station, College of Agricultural Sciences. Mayagüez Campus, University of Puerto Rico.

${ }^{5}$ Associate Professor, Department of Annimal Sciences, Agricultural Experiment Station, College of Agricultural Sciences. Mayagüez Campus, University of Puerto Rico 


\section{RESUMEN}

Uso del ensayo de inhibición de migración larval para la evaluación de resistencia antihelmíntica de novillas lecheras en Puerto Rico

La resistencia antihelmíntica de ivermectina (IVM) en Cooperia spp. de novillas lecheras de Puerto Rico se evaluó mediante el ensayo de inhibición de la migración de larvas (LMIA, por sus siglas en inglés). La tercera etapa larval $\left(L_{3}\right)$ se recuperó a partir de cultivos fecales pre tratamiento en ocho fincas donde se evaluó previamente la resistencia antihemíntica con el uso de una prueba de reducción del conteo de huevos fecales (FECRT, por sus siglas en inglés). La concentración efectiva donde se inhibe el $50 \%$ de la migración de las larvas $\left(\mathrm{EC}_{50}\right)$ se obtuvo a partir de cepas susceptibles y resistentes de Cooperia spp. aisladas en una de las fincas. Las larvas susceptibles se caracterizaron por un $\mathrm{EC}_{50}$ de $0.7224 \mu \mathrm{M}$ y las resistentes por un $\mathrm{EC}_{50}$ de 7.0778 $\mu \mathrm{M}$. Este resultado indica que en promedio las larvas del aislado resistente son 10X más resistentes que las del aislado susceptible. Sin embargo, el LMIA no fue capaz de discriminar consistentemente entre las larvas susceptibles y resistentes obtenidas de las fincas evaluadas. En uno de los casos, un valor de $\mathrm{EC}_{50}$ de $0.7263 \mu \mathrm{M}$, cercano al valor obtenido con el aislado susceptible, no coíncidía con el resultado de FECR de $-136.19 \%$ documentado en esa finca. En dos ocasiones más la prueba no pudo discriminar entre los aislados resistentes y susceptibles. De hecho, los valores de $\mathrm{EC}_{50}$ de LMIA obtenidos de algunos aislados resistentes eran menores que los valores de $\mathrm{EC}_{50}$ de los aislados susceptibles, aunque sus resultados de FECRT indicaran que había resistencia a IVM. Posiblemente, el FECRT dio resultados falso positivos debido a la presencia de resistencia de lactonas macrocíclicas en esas dos fincas. Por lo tanto, se requieren más estudios para validar la efectividad de LMIA para detectar la resistencia antihelmíntica a lactonas macrocíclicas en larvas de Cooperia spp. aisladas de muestras fecales de bovinos.

Palabras clave: Ivermectina, Cooperia, lactonas macrocíclicas, conteo de huevos fecales

\section{INTRODUCTION}

It is important to be able to detect anthelmintic resistance at low levels as early as possible in order to delay the spread of anthelmintic resistance in parasite species that have an impact on the development and health of food producing animals (Demeler et al., 2010a). As an alternative for the early detection of anthelmintic resistance, several in vitro assays have been developed. In vitro tests involve the incubation of one of the parasite's free living stages in a range of concentrations of a drug and the measurement of a variable such as the vitality, motility or migration to generate a dose response value (Demeler et al., 2010a).

The larval migration inhibition assay (LMIA) is an in vitro assay that involves the incubation of the $\mathrm{L}_{3}$ larval stage in different concentrations of an anthelmintic followed by migration of the larvae through a fine mesh sieve. This assay is based on the principle that drug resistant larvae are able to migrate through the sieve whereas drug susceptible larvae remain trapped in the sieve. A dose response can then be calculated in order to determine the relative susceptibility of the parasites to 
the drug and whether resistance is present in the parasite population (Taylor et al., 2002). Since the infective third stage larvae do not feed, the effects of a given drug on the ability of the larvae to migrate through the sieve are thought to be related to paralysis of the body musculature (Demeler et al., 2010b). Therefore, this assay is only valid for the detection of anthelmintic resistance to macrocyclic lactones.

\section{MATERIALS AND METHODS}

Ivermectin resistant and susceptible Cooperia spp. isolates

Resistant Cooperia spp. $\mathrm{L}_{3}$ isolates were provided by Dr. Gil Myers' Lab (Myers Parasitology Services) ${ }^{6}$ in Magnolia, KY. Larvae were recovered from calves treated with ivermectin (IVM) that had a negative drug efficacy. Susceptible Cooperia spp. isolates were obtained from larvae recovered at a commercial farm in Puerto Rico, which were characterized as susceptible by an IVM fecal egg count reduction (FECR) of $96.67 \%$.

Field isolates of $L_{3}$ recovered from fecal samples from dairy farms in Puerto Rico

From September to December 2012, fecal samples were collected from 10 farms previously evaluated by FECRT. Fecal samples were then refrigerated and sent to the University of Georgia in Athens, GA. Pooled feces from selected farms were mixed with vermiculite (Sargent-Welch, Buffalo, NY) and incubated for 10 days at room temperature $\left(25^{\circ} \mathrm{C}\right)$. The cultures were examined and stirred every day. To prevent larval desiccation, distilled water was added as needed. After 10 days of incubation, the $\mathrm{L}_{3}$ were recovered using the Baermann technique (Dinaburg, 1942), in which the pooled fecal matter is suspended over a sieve inside a funnel with lukewarm water for 24 hours. Recovered larvae were stored at $10^{\circ} \mathrm{C}$ in deionized water and used within three months after collection. Larvae species were stained using a $10 \%$ Lugol's iodine solution and identified using morphological characteristics of the anterior end, tail sheath extension and overall body length (Van Wyk et al., 2004).

Larval migration inhibition assay procedure

A $10 \mathrm{mM}$ stock solution of IVM was prepared using $100 \%$ dimethyl sulfoxide (DMSO) (Fisher Chemical, Rochester, New York) and stored

\footnotetext{
${ }^{6}$ Company or trade names in this publication are used only to provide specific information. Mention of a company or trade name does not constitute an endorsement by the Agricultural Experiment Station of the University of Puerto Rico, nor is this mention a statement of preference over other equipment or materials.
} 
in aliquots at $-30^{\circ} \mathrm{C}$ for a maximum of three months. Working solutions were prepared using four-fold dilutions of IVM in 100\% DMSO for a series of final concentrations in the plate of $20 \mu \mathrm{M}, 5.0 \mu \mathrm{M}, 1.25$ $\mu \mathrm{M}, 0.3125 \mu \mathrm{M}, 0.0781 \mu \mathrm{M}, 0.0195 \mu \mathrm{M}$ and $0.0049 \mu \mathrm{M}$. Negative controls consisted of live larvae that were incubated in a non-drug solution consisting of $1 \%$ DMSO in Phosphate Buffered Saline (PBS) $0.01 \mathrm{M}$ (Sigma BioReagent).

The LMIA procedure was performed using standard 24-well culture plates (Costar, NY). The plate consisted of triplicate concentrations of IVM (Sigma 18898, St. Louis, MO) and a control (no IVM). Third stage larvae were counted and aliquots of $80 \mathrm{~L}_{3} / 100 \mu \mathrm{L}$ of $\mathrm{dH}_{2} \mathrm{O}$ were prepared and pipetted into each well following the experimental design. Additionally, $100 \mu \mathrm{L}$ of an incubation solution at $2 \mathrm{x}$ the final plate concentration of $1 \%$ DMSO in PBS was prepared for each drug concentration and pipetted into each of the 24 wells of the incubation plate. Both solutions were vortexed vigorously and frequently to ensure homogeneity in each well.

After 24 hours of incubation, the $\mathrm{L}_{3}$ were transferred to a migration plate containing four migration racks. Each rack consisted of six sieves made from clear Plexiglas XT tubes (Brinke $\mathrm{KG}$, id $=8-9$ $\mathrm{mm} / \mathrm{od}=11.5 \mathrm{~mm}$ ) cut to the length of $2 \mathrm{~cm}$ and glued to a Plexiglas stick. At the end of each sieve, a $28 \mu \mathrm{m}$ precision woven nylon polyamid mesh was glued (Figure 1). Each well in the migration plate was loaded with $1.8 \mathrm{~mL}$ of a migration solution at $1 \mathrm{x}$ the final plate concentration of $1 \%$ DMSO in PBS. The contents of the incubation plate (larvae suspension and incubation solution) were transferred onto the top of the sieves following the plate design. Plates were examined under a stereoscope to confirm that no larvae remained. The $\mathrm{L}_{3}$ were left to migrate for 24 hours in the dark at room temperature $\left(25^{\circ} \mathrm{C}\right)$. The migration racks were gently removed from the migration plate and inverted over the non-migration plate. The non-migrated larvae were carefully rinsed into the corresponding plate using a washing bottle with $\mathrm{dH}_{2} \mathrm{O}$.

\section{Statistical analysis of LMIA}

The number of migrated and non-migrated larvae in the plates were counted for each drug concentration. The negative controls and the respective percentages of migration were calculated. Dose response data, to determine the effective concentration at which $50 \%$ of larval migration is inhibited $\left(\mathrm{EC}_{50}\right)$, were analyzed using the "One population" logistic regression model of the Fit Logit Program (Dobson et al., 1987; Waller et al., 1985). 


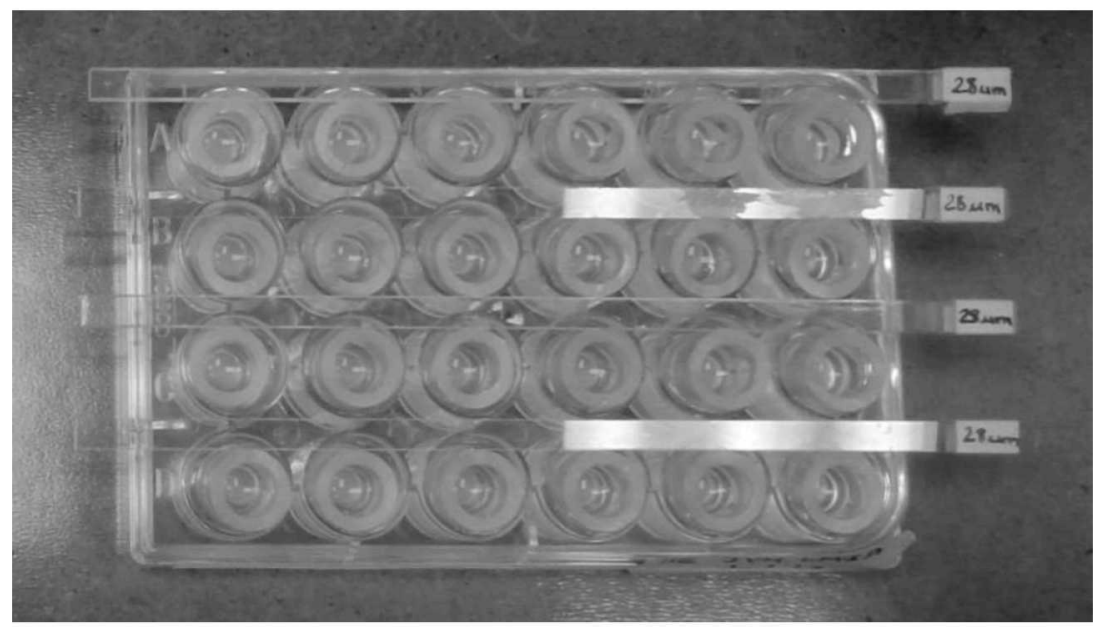

FIGURE 1. Migration plate used for LMIA. The plate consisted of a 24-well tissue culture plate with four migration racks, each of which was composed of six circular plexiglass tubes with a $28 \mu \mathrm{m}$ mesh glued to the bottom.

\section{RESULTS AND DISCUSSION}

The calculated $\mathrm{EC}_{50}$ for the eight farms evaluated are presented in Table 1. For the resistant and susceptible Cooperia spp. isolates, $\mathrm{EC}_{50}$ were $7.0778 \mu \mathrm{M}$ and $0.7224 \mu \mathrm{M}$, respectively. Dose response curves were generated using a logistic regression model (Figure 2). A shift in curves towards the right of the IVM susceptible isolate indicates the presence of drug resistance. Conversely, curves displaced towards the left of the susceptible isolate curve are descriptive of susceptibility. Isolates obtained from Farms 2, 16 and 18 had $\mathrm{EC}_{50}$ that were below the $\mathrm{EC}_{50}$ of the susceptible isolate.

The larval migration inhibition assay has been proposed as an alternative for the early detection of anthelmintic resistance. This assay has been recently standardized for use in cattle (Demeler et al., 2010a; $2010 \mathrm{~b}$ ), but published data obtained using this proposed method are still scarce. Most evaluations of anthelmintic resistance using LMIA employ monocultures of Cooperia oncophora isolates. Demeler et al. (2010a) reported $\mathrm{EC}_{50}$ values of $123 \mathrm{nM}$ and $621 \mathrm{nM}$ for susceptible and resistant isolates, respectively. Additionally, C. oncophora had an $\mathrm{EC}_{50}$ of $0.107 \mu \mathrm{M}$ in susceptible larvae using LMLA for IVM resistance evaluation (Demeler et al., 2010b). Similar studies in Belgium, where LMIA was used to evaluate the IVM resistance of $C$. oncophora showed 
TABLE 1.-Effective anthelmintic concentration required to paralyze 50\% of the larvae $\left(E C_{50}\right.$ ) evaluated by LMIA for each farm isolate. Susceptible (S), and resistant (R) Cooperia spp. control larvae are also presented in this table.

\begin{tabular}{lcc}
\hline Farm & $\mathrm{EC}_{50}(\mu \mathrm{M})$ & FECR $(\%)$ \\
\hline $\mathrm{R}$ & 7.0778 & negative \\
$\mathrm{S}$ & 0.7224 & 96.67 \\
0 & 0.4637 & - \\
2 & 0.7263 & -136.19 \\
5 & 1.9080 & 65.94 \\
11 & 8.3016 & -414.13 \\
13 & 2.9415 & -37.63 \\
16 & 0.3650 & 24.45 \\
18 & 0.3959 & 85.50 \\
\hline
\end{tabular}

that susceptible isolates of this species had an $\mathrm{EC}_{50}$ of $0.120 \mu \mathrm{M}(\mathrm{El}-$ Abdellati et al., 2010).

Recently, LMLA was used to evaluate IVM resistance of Cooperia spp. affecting cattle in Brazil and migration differences were detected between resistant and susceptible isolates, the latter presenting an $\mathrm{EC}_{50}$ value of $1.16 \eta \mathrm{mol}$ (Almeida et al., 2013). Cooperia spp. is considered the dose-limiting species, meaning that compared to other gastrointestinal nematode species, a higher dose of a given drug is necessary to eradicate this parasite (Vercruysse, 2002). There is some evidence that $L_{3}$ are less susceptible to the effects of macrocyclic lactones than other stages of this parasite (Demeler et al., 2010b).

In the present study, the LMIA was unable to consistently discriminate between susceptible and resistant larvae obtained from dairy farms evaluated in Puerto Rico. The average $\mathbf{E C}_{50}$ determined for the susceptible and resistant isolates was $0.7224 \mu \mathrm{M}$. and $7.0778 \mu \mathrm{M}$, respectively. This indicates that on average, larvae from the resistant isolate are $10 \mathrm{X}$ more resistant than those from the susceptible isolates. However, LMIA results from Farm 2 presented an $\mathrm{EC}_{50}$ of $0.7263 \mu \mathrm{M}$, which is close to that of the susceptible isolate and does not agree with the FECR of -136.19\% determined for this farm. It is unclear why in this case FECRT and LMIA differ in their determination of anthelmintic resistance status. Additional instances in which the assay was unable to discriminate are seen in the LMIA results for Farms 16 and 18 , where both $\mathrm{EC}_{50}$ values were lower than the $\mathrm{EC}_{50}$ of the susceptible isolate, whereas their FECRT results indicated that resistance to IVM was present. Another possibility is that the previous FECRT could have indicated a false positive for resistance to macrocyclic lactones at these farms. 


\section{PR Cattle IVM LMIA}

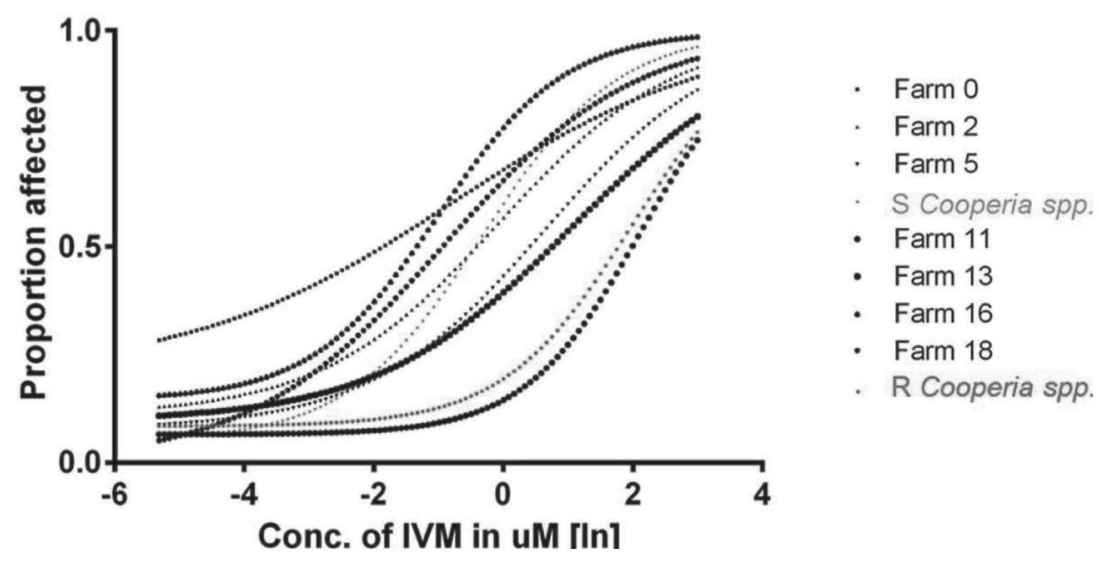

FIGURE 2. Dose-response curves for IVM ( $\mu$ M) obtained by LMIA of Cooperia spp. isolates from seven farms in Puerto Rico. Susceptible (S) Cooperia spp. $\mathrm{EC}_{50}$ and resistant (R) Cooperia spp. $\mathrm{EC}_{50}$ isolates are also shown.

Anthelmintic resistance is a serious problem affecting the cattle industry in many countries. In Brazil, the evaluation of anthelmintic resistance of Cooperia spp. isolates using the LMIA was able to differentiate between susceptible and resistant field isolates, suggesting the possibility that this assay can be employed in the future for detecting drug resistance of this parasite, which is the most predominant in the tropics. In the present study, LMIAs were performed using Cooperia spp. isolates recovered from fecal cultures obtained from heifers of local dairy farms. The discrepant results in which the same farms with a negative FECRT yielded disagreeing $\mathbf{E C}_{50}$ values determined by LMIA, might mean that either the LMIA was unreliable in differentiating between the susceptible and resistant isolates, or the FECRT gave a false positive for anthelmintic resistance. Consequently, additional research is needed to evaluate LMLA as a tool to detect anthelmintic resistance to macrocyclic lactones from field samples.

\section{LITERATURE CITED}

Almeida, G.D., D.C. Feliz, R.P. Heckler, D.G.L. Borges, M.K.V. Onizuka, L.E.R. Tavares, F. Paiva and F.A. Borges, 2013. Ivermectin and moxidectin resistance characterization by larval migration inhibition test in field isolates of Cooperia spp. in beef cattle, Mato Grosso do Sul, Brazil. Veterinary Parasitology 191(1-2): 59-65.

Demeler, J., U. Küttler, A. El-Abdellati, K. Stafford, A. Rydzik, M. Varady, F. Kenyon, G. Coles, J. Höglund, F. Jackson, J. Vercruysse and G. Von Samson-Himmelstjerna, 
2010b. Standardization of the larval migration inhibition test for the detection of resistance to ivermectin in gastro intestinal nematodes of ruminants. Veterinary Parasitology 174(1-2): 58-64.

Demeler, J., U. Küttler and G. Von Samson-Himmelstjerna, 2010a. Adaptation and evaluation of three different in vitro tests for the detection of resistance to anthelmintics in gastro intestinal nematodes of cattle. Veterinary Parasitology 170(1-2): 61-70.

Dinaburg, A.G., 1942. The efficiency of the Baermann apparatus in the recovery of larvae of Haemonchus contortus. The Journal of Parasitology 28(6): 433-440.

Dobson, R.J., D.A. Griffiths, A.D. Donald and P.J. Waller, 1987. A genetic model describing the evolution of levamisole resistance in Trichostrongylus colubriformis, a nematode parasite of sheep. Journal of Mathematics Applied in Medicine and Biology 3(3): 279-293.

El-Abdellati, A., P. Geldhof, E. Claerebout, J. Vercruysse and J. Charlier, 2010. Monitoring macrocyclic lactone resistance in Cooperia oncophora on a Belgian cattle farm during four consecutive years. Veterinary Parasitology 171(1-2): 167-171.

Taylor, M.A., K.R. Hunt and K.L. Goodyear, 2002. Anthelmintic resistance detection methods. Veterinary Parasitology 103(3): 183-194.

Van Wyk, J.A., Van, J. Cabaret and L.M. Michael, 2004. Morphological identification of nematode larvae of small ruminants and cattle simplified. Veterinary Parasitology 119: 277-306. Vercruysse, J., 2002. General efficacy of the macrocyclic lactones to control parasites of cattle. Macrocyclic Lactones in Antiparasitic Therapy (pp. 185222). CABI Publishing, Wallingford Oxfordshire.

Waller, P.J., R.J.Dobson, A.D. Donald, D.A. Griffiths and E.F. Smith, 1985. Selection studies on anthelmintic resistant and susceptible populations of Trichostrongylus colubriformis of sheep. International Journal for Parasitology 15(6): 669-676. 